\title{
KEMPEN DAN PROPAGANDA AKHBAR TEMPATAN FILIPINA TERHADAP ISU TUNTUTAN KE ATAS BORNEO UTARA, 1961-1963
}

\author{
Norizan Binti Kadir \\ Danny Wong Tze Ken
}

\begin{abstract}
On 30 December 1961, the governments of Britain, North Borneo and the Federation of Malaya were shocked by the provocative article published by the Philippine Free Press. The article entitled "North Borneo is Ours" written by Napoleon G. Rama, a prominent journalist in the Philippines, created tension and dissatisfaction among the leaders of Malaya, North Borneo and the British Government. Leaders and media practitioners in Malaya condemned the Philippine media as not being professional and believed such actions was a ploy to delay the creation of Malaysia which was announced by Tunku Abdul Rahman on 27 May 1961. Other Philippine's newspapers such as Manila Times, Philippine Herald, Manila Chronicle, Daily Mirror, The Evening News and the Manila Daily Bulletin also published provocative articles on the North Borneo claim. The propaganda by the Philippine's newspapers pertaining to the North Borneo issue succeeded in influencing the decision of Republic of the Philippines to take an effective step by sending an aide-memoire to the British in order to challenge British sovereignty over North Borneo. This article examines selected Philippine newspapers to show how their rigorous campaign and propaganda on the North Borneo issue shaped Philippine foreign policy on the dispute.
\end{abstract}

\section{Pengenalan}

Pasca kemerdekaan negara-negara di rantau Asia Tenggara merupakan satu fasa ke arah pembinaan negara bangsa yang memperlihatkan satu ciri penting iaitu persaingan negaranegara serantau bagi meluaskan wilayah kekuasaan sekali gus mengukuhkan kedaulatan sempadan negara masing-masing. Keadaan inilah yang mendorong Republik Filipina mula mengambil inisiatif yang pragmatik bagi menuntut Borneo Utara (Sabah) pada tahun 1962 sebelum pembentukan Malaysia berjaya direalisasikan. Hasrat Filipina untuk mendapatkan Borneo Utara bukanlah satu idea baru yang ditimbulkan oleh Presiden Diosdado Macapagal, tetapi ia sudah muncul lebih lama yakni setelah Filipina mencapai kemerdekaan lagi. Namun, ia tidak wujud dalam bentuk satu rancangan yang khusus dan teliti memandangkan Filipina sendiri tidak mempunyai bukti-bukti yang kukuh untuk mengesahkan dakwaannya.

Perbincangan mengenai isu tuntutan Filipina ke atas Borneo Utara banyak dibincangkan oleh sarjana-sarjana dalam bidang perundangan dan hubungan antarabangsa sejak Filipina mengemukakan rasminya pada 22 Jun 1962. Kebanyakannya perbincangan terdahulu memfokuskan kepada faktor-faktor perundangan seperti asas-asas dan justifikasi tuntutan Filipina ke atas Borneo Utara. Tidak banyak perbincangan yang memberikan penekanan kepada aspek-aspek dialektik sehingga mempengaruhi pembentukan polisi luar Filipina terhadap Borneo Utara. Antara elemen penting yang begitu menonjol dalam konteks ini adalah peranan yang dimainkan oleh media Filipina, khususnya akhbar-akhbar tempatan Filipina bagi mendesak ahli-ahli Dewan Perwakilan dan Dewan Senat Filipina supaya segera menuntut Borneo Utara. Peranan akhbar-akhbar tempatan Filipina menyebarkan propaganda isu Borneo Utara menatijahkan kesan yang begitu signifikan apabila Filipina akhirnya mengambil pendirian untuk menuntut Borneo Utara.

Bermula dari bulan pertama pada tahun 1962, isu Borneo Utara umpama 'pisang goreng panas' yang menghiasi dada-dada akhbar tempatan Filipina. Tidak kurang juga, 
terdapat pelbagai fakta yang diselewengkan dan ditokok tambah bagi mencetuskan provokasi dan mendesak Republik Filipina supaya menuntut Borneo Utara daripada Kerajaan British. Hakikatnya, isu kedaulatan Borneo Utara sudah lama dicetuskan oleh media Filipina seperti Philippines Free Press iaitu pada Disember 1961 iaitu selepas Pilihan Raya Umum Filipina diadakan. Namun, hanya pada bulan pertama dan seterusnya pada tahun 1962, isu Borneo Utara makin berkembang sehingga wujud kempen yang lebih khusus dan besar-besaran bagi menuntut semula Borneo Utara secara serius. Keadaan ini juga adalah sebagai tanda protes terhadap idea pembentukan Malaysia yang dikemukakan oleh Tunku Abdul Rahman pada 27 Mei 1961 yang melibatkan penggabungan Borneo Utara, Persekutuan Tanah Melayu, Sarawak, Brunei dan Singapura. Duta Australia di Manila juga menyifatkan kempen menyebarkan propaganda tuntutan ke atas Borneo Utara sebagai respons terhadap cadangan pembentukan Malaysia. Menurutnya, dua bulan sejak pengumuman pembentukan Malaysia dibuat, kempen menuntut semula Borneo Utara telah dilancarkan bagi mendesak Republik Filipina mempertahankan haknya ke atas Borneo Utara. Beliau juga turut menyatakan kebimbangannya terhadap perkembangan tersebut memandangkan sudah terdapat beberapa orang pegawai kerajaan Filipina yang sudah mula terpengaruh dengan propaganda kempen tersebut.

Di peringkat awal kempen tersebut bermula, terdapat dua akhbar utama di Filipina yang cuba menghidupkan isu Borneo Utara iaitu Philippine Free Press dan Evening News. Namun, lama-kelamaan iaitu dalam tempoh enam bulan pertama tahun 1962, isu Borneo Utara kemudiannya bertukar menjadi isu nasional yang semakin sukar untuk diketepikan apabila terdapat lebih ramai wartawan dan kolumnis dalam akhbar tempatan lain yang cuba menambahkan provokasi dengan menyuburkan isu Borneo Utara dengan pelbagai kepentingan. Keadaan ini seterusnya menjadi satu kempen akhbar Filipina yang dilakukan secara konsisten dan besar-besaran bagi menuntut Borneo Utara daripada British sebelum pembentukan Malaysia.

Isu Borneo Utara telah dibangkitkan oleh akhbar Filipina bagi mengulangi tuntutan waris-waris Sultan Sulu terutamanya daripada keluarga Kiram yang masih tidak berpuas hati dengan perjanjian penyerahan kawasan Pantai Timur Borneo Utara oleh Sultan Jamalul 'Alam kepada Baron Von Overbeck pada 22 Januari 1878. Dalam perjanjian tersebut, Sultan Jamalul 'Alam telah menyerahkan wilayah di Pantai Timur Borneo Utara kepada Overbeck yang meliputi wilayah dari Sungai Pandasan di bahagian pantai barat merentangi seluruh bahagian di kawasan pantai timur hingga ke Sungai Sibuko di timur.

Waris-waris Sultan Sulu beranggapan perjanjian penyerahan tersebut hanyalah bersifat pajakan dan kedaulatan Borneo Utara masih kekal menjadi milik Kesultanan Sulu. Pendirian yang sama turut diulangi oleh wartawan-wartawan akhbar Filipina yang menyokong tuntutan waris-waris Sultan Sulu dan melakukan pelbagai usaha bagi membuka mata dan meraih sokongan masyarakat Filipina keseluruhannya untuk mendesak Kerajaan Filipina menuntut Borneo Utara. Menerusi kempen tersebut, ia telah berjaya mengangkat isu tuntutan ke atas Borneo Utara sebagai isu nasional yakni bukan lagi dalam konteks parokial iaitu isu wilayah warisan yang melibatkan etnik Sulu semata-mata. Oleh itu, tulisan ini akan membincangkan pengaruh kempen oleh akhbar tempatan Filipina terhadap pembentukan dasar Filipina terhadap persoalan Borneo Utara. Sebahagian besar bahan sumber pertama yang dirujuk dalam tulisan ini diperoleh menerusi kajian di National Archive, London, National Archive of Singapore, National Library of Philippines, Arkib Negara Malaysia, Arkib Negeri Borneo Utara, Institute of Southeast Asian Studies (Singapura).

\section{Kempen Akhbar Filipina Terhadap Isu Tuntutan Filipina ke atas Borneo Utara}

Penyebaran propaganda terhadap persoalan Borneo Utara di dalam akhbar arus perdana di Filipina dilakukan menerusi beberapa pendekatan iaitu penerbitan rencana, kolum khas oleh 
kolumnis jemputan dan artikel editor. Keadaan ini akhirnya telah berjaya mewujudkan lingkungan pengaruh yang bersifat kolektif terhadap persoalan Borneo Utara yang bermatlamatkan untuk menggesa Republik Filipina mengambil langkah-langkah menuntut Borneo Utara. Antara akhbar utama yang menjalankan kempen penyebaran propaganda untuk menuntut semula Borneo Utara adalah Philippines Free Press, Manila Times, Philippine Herald, Manila Chronicle, Daily Mirror, Evening News dan Manila Daily Bulletin. ${ }^{1}$

Perbahasan mengenai isu Borneo Utara mula mendapat perhatian serius daripada akhbar-akhbar tempatan Filipina apabila beberapa wartawan seperti Napoleon G. Rama berminat untuk mengetengahkan dakwaan Nicasio Osmena mengenai pemilikan waris-waris Sultan Sulu ke atas Borneo Utara. Osmena yang mendakwa dirinya sebagai peguam yang dilantik oleh waris-waris Sultan Sulu bagi menuntut semula Borneo Utara dari pihak British. ${ }^{2}$ Usahanya untuk meraih simpati media Filipina dan Republik Filipina sendiri untuk menuntut Borneo Utara hakikatnya sudah berlangsung beberapa tahun sebelum itu lagi, namun tiada wartawan mahupun politikus Filipina yang benar-benar berminat untuk membuat liputan mengenainya dan menyokong usaha tersebut. Hal ini demikian kerana, mereka sendiri meragui kebenaran dakwaan yang dikemukakan oleh Osmena apatah lagi waris-waris Sultan Sulu yang sah sendiri menafikan pelantikan beliau sebagai peguam mereka. Tambahan pula, dalam suasana Filipina yang bakal menghadapi Pilihan Raya Presiden pada bulan November 1961, maka tumpuan dan perhatian utama liputan akhbar lebih memfokuskan kepada kempenkempen calon Presiden Filipina. Hanya selepas itu, barulah usaha Osmena membuahkan hasil apabila beliau berjaya mendekati Rama dan memujuknya untuk mendengar penjelasan mengenai tuntutan oleh waris-waris Sultan Sulu ke atas Borneo Utara. Bagi Rama, beliau menganggap segala dakwaan Osmena tersebut ada kebenarannya berdasarkan dokumendokumen yang beliau kemukakan.

Akhbar tempatan Filipina telah menggunakan pendekatan kempen secara besarbesaran semenjak Januari 1962 bagi menyebarkan propaganda dan provokasi untuk mendesak Republik Filipina mengambil langkah sewajarnya menuntut Borneo Utara. Antara tulisan terawal yang telah mencetuskan kontroversi adalah tulisan wartawan, Napoleon G. Rama yang turut mewujudkan ketegangan dan keadaan kurang senang di antara tiga buah negara iaitu Tanah Melayu, British dan Filipina. Hal ini berikutan daripada tulisannya yang bertajuk North Borneo is Ours di dalam akhbar Philippines Free Press ${ }^{3}$ pada 20 Januari 1962. ${ }^{4}$ Artikel tersebut ditulis bagi menggesa dan mempengaruhi ahli dewan yang baru sahaja dibentuk sewaktu pilihan raya sebelum itu bagi mengambil tindakan menuntut Borneo Utara. Pendekatan oportunisme dan perang psikologi ini juga dilihat sangat kena pada waktunya memandangkan sebelum pilihan raya pada Disember 1961, Macapagal dalam kempen pilihan rayanya turut berjanji untuk mengambil langkah ke arah menuntut semula Borneo Utara daripada Kerajaan British. Hal ini menjadi suatu kelebihan kepada akhbar Filipina untuk menuntut semula janji-janji manis Macapagal selepas berakhirnya pilihan raya selain ditambah dengan desakan daripada waris-waris Sultan Sulu.

Meskipun isu tuntutan ke atas Borneo Utara sudah lama dihidupkan oleh keluarga Kiram dan waris-waris Sultan Sulu yang lain sejak sebelum Filipina mencapai kemerdekaan lagi iaitu pada tahun 1946, namun ia masih gagal meraih sokongan masyarakat Filipina apatah lagi Kerajaan Filipina untuk menyokongnya sehinggalah akhbar Filipina mula memberikan perhatian serius terhadap isu tersebut. ${ }^{5}$ Keadaan ini juga berpunca daripada Filipina pada ketika itu tidak mempunyai bukti yang secukupnya untuk mengesahkan kedaulatannya terhadap Borneo Utara. Selepas kematian Sultan Jamalul Kiram II juga memperlihatkan usaha waris-waris Sultan Sulu yang cuba menuntut Borneo Utara selain turut menuntut bayaran lump sum daripada pihak British kerana menduduki Borneo Utara. Pelbagai usaha dilakukan termasuklah dengan mengupah peguam-peguam bagi menuntut Borneo Utara. ${ }^{6}$ Walau bagaimanapun, ia masih gagal meraih perhatian British untuk mempertimbangkan tuntutan 
tersebut. Usaha demi usaha terus dilakukan oleh waris-waris Sultan Sulu bagi mendapatkan Borneo Utara daripada pihak British termasuklah membatalkan Perjanjian Serahan 1878 pada 25 November $1957 .^{7}$

Pembatalan perjanjian tersebut dibuat oleh Sultan Esmail Kiram yang ditabal oleh waris-waris Sultan Sulu sebagai Sultan Sulu menggantikan Dayang Dayang Hadji Piandao sebagai pemangku sultan. Notis pembatalan yang berkuat kuasa pada 22 Januari 1958 itu mengisytiharkan pemulangan semula seluruh tanah seperti yang dinyatakan di dalam perjanjian 1878 kepada Kesultanan Sulu. Salinan notis bantahan tersebut juga turut dihantar kepada pejabat British North Borneo di Jesselton, pejabat British North Borneo di London, Kementerian Hal Ehwal Luar British, pejabat kedutaan British di Manila, Setiausaha Hubungan Luar Filipina dan Setiausaha Agung Pertubuhan Bangsa-Bangsa Bersatu (PBB) di New York. ${ }^{8}$ Penghantaran salinan notis bantahan tersebut kepada ramai pihak sengaja dilakukan oleh Sultan Esmail Kiram dengan nasihat peguamnya bagi meraih perhatian dan sokongan daripada pihak-pihak tersebut sekali gus menjatuhkan imej British yang didakwa mentadbir Borneo Utara secara tidak sah. Hal tersebut walau bagaimanapun masih gagal meraih simpati dan perhatian Republik Filipina pada ketika itu yang dipimpin oleh Carlos P. Garcia.

Pada peringkat awal, isu yang menjadi perhatian dan tumpuan utama akhbar Filipina adalah dengan mempersoalkan pemilikan sebenar ke atas Borneo Utara dan mengaitkannya dengan penyerahan kawasan Pantai Timur Borneo Utara kepada Sultan Sulu. ${ }^{9}$ Akhbar Filipina berusaha untuk mewajarkan tuntutan ke atas Borneo Utara dengan mengemukakan pelbagai fakta dan hujah yang memihak kepada Republik Filipina dan waris Sultan Sulu. Ia sengaja dilakukan bagi meraih sokongan dan perhatian daripada seluruh rakyat dan pentadbiran Filipina bagi berkongsi hasrat yang sama iaitu menuntut Borneo Utara. Dalam artikel bertajuk North Borneo Belongs To Us tulisan Napoleon G. Rama, beliau menegaskan Borneo Utara adalah sebahagian wilayah Republik Filipina. Menurut beliau:

... From almost every standpoint, North Borneo rightfully belongs to the Philippines. Our government has been negligent in asserting its sovereignty over the area. It is time for the Philippine Government under the new administration to wake up. $^{10}$

Napoleon G. Rama ketika menghasilkan artikel kontroversinya turut merujuk sebahagian dokumen penting yang diperoleh daripada Arkib Sepanyol berhubung perjanjian di antara Sultan Sulu dan Baron. ${ }^{11}$ Beliau juga mengulangi pendirian waris-waris Sultan Sulu bahawa Perjanjian 1878 tersebut adalah bersifat pajakan atau "leased" semata-mata dan bukannya penyerahan berkekalan. Bagi mengukuhkan hujahnya, beliau mengaitkan pemberian wang pajakan yang diberikan secara tahunan oleh British North Borneo Company (BNBC) kepada Sultan Sulu sebanyak \$5300 sebagai bukti ianya bersifat pajakan. Hubungan dan kerjasamanya dengan Nicasio Osmena, anak kepada bekas Presiden Filipina yang menjadi peguam kepada waris-waris Sultan Sulu daripada Keluarga Kiram menyebabkan usahanya untuk mempertahankan tuntutan ke atas Borneo Utara semakin mendapat perhatian ramai.

Beliau juga cuba mempertahankan dakwaannya bahawa Filipina juga berhak ke atas Borneo Utara meskipun Kerajaan Sulu yang sebenarnya mempunyai kedaulatan ke atas Borneo Utara. Menurut beliau, Filipina berhak ke atas kedaulatan Borneo Utara memandangkan waris-waris Sultan Sulu juga adalah 'Filipino' atau warganegara Filipina. ${ }^{12}$ Beliau juga menyelar kelemahan pentadbiran Filipina yang dikatakan gagal bertindak sewajarnya bagi menuntut semula Borneo Utara. ${ }^{13}$ Di samping itu, akhbar-akhbar Filipina 
juga turut membuat liputan khas mengenai waris-waris Sultan Sulu yang cuba menuntut semula Borneo Utara termasuklah Putri Tarhata Kiram. Putri Tarhata Kiram dalam usahanya untuk menuntut Borneo Utara telah merayu kepada Jabatan Hal Ehwal Luar Filipina melalui peguamnya, J. C. Orendain untuk menyokong tuntutannya ke atas Borneo Utara. ${ }^{14}$ Akhbar Manila Chronicle dalam penerbitannya turut menyiarkan kenyataan Putri Tarhata Kiram yang menyelar kepimpinan Presiden Quezon kerana memansuhkan pengiktirafan ke atas Institusi Kesultanan Sulu yang didakwa Putri Tarhata sebagai tidak sah dan menjadi kelebihan buat British untuk terus menguasai Borneo Utara.

Ernesto del Rosario dalam tulisannya di akhbar The Manila Chronicle dengan ketara juga turut menyokong isu tuntutan Filipina ke atas Borneo Utara bagi mempertahankan hak waris Sultan Sulu daripada Keluarga Kiram. ${ }^{15}$ Sokongan yang diberikan kepada waris Sultan Sulu tersebut adalah sebagai usaha untuk menangani masalah yang melibatkan masyarakat Muslim di Selatan Filipina. Kesedaran ini timbul sebagai reaksi terhadap tuntutan masyarakat Muslim di Selatan Filipina yang mahukan autonomi dalam pentadbiran daripada Republik Filipina. Justeru, bantuan diberikan kepada waris Sultan Sulu mendapatkan semula Borneo Utara, dengan harapan Borneo Utara dapat bernaung di bawah Republik Filipina dengan Kesultanan Sulu bertindak sebagai pentadbir di Borneo Utara. Ernesto O. Granada pula dalam komentarnya yang menyokong tuntutan formal dibuat ke atas Borneo Utara menyifatkan tindakan tersebut sebagai satu penghargaan dan penghormatan kepada Amerika Syarikat di atas segala usaha membangunkan Filipina. Beliau menjelaskan, "now is perhaps our chance to repay the American benevolence of the past half century by pursuing a policy of "manifest destiny" and guiding North Borneo to the path of Christianity and democracy." 16 Beliau yang juga merupakan antara penulis berpengaruh di Filipina turut menyatakan kekagumannya terhadap perkembangan semasa mengenai isu Borneo Utara yang disifatkan beliau sebagai "unexpected fast boil” ekoran daripada kesungguhan dan kerja keras Osmena dengan sokongan yang diberikan oleh Datuk Bandar Filipina, Arsenio H. Lacson. ${ }^{17}$

Bagi merealisasikan matlamat utama kempen iaitu menuntut Borneo Utara dari pihak British sebelum pembentukan Malaysia, pelbagai usaha dilakukan oleh wartawan Filipina bagi memperlihatkan sokongan penduduk Borneo Utara sendiri terhadap Filipina. Antaranya, akhbar Philippine Free Press bertarikh 31 Mac 1962 turut menerbitkan kenyataan dan sokongan oleh dua orang penduduk Muslim di Sandakan dan Labuan serta seorang penduduk Cina di Singapura yang menyokong tuntutan Filipina ke atas Borneo Utara. Kedua-dua penduduk Borneo Utara tersebut adalah Ahmad Sambunong, seorang pedagang kopra di Sandakan dan Ibrahim Abidin yang merupakan bekas guru besar sekolah. ${ }^{18}$ Lebih memeranjatkan lagi pada ketika itu apabila Ajala, seorang wartawan Nigeria yang mengadakan lawatannya ke Borneo Utara telah membuat liputan mengenai reaksi penduduk Borneo Utara terhadap cadangan pembentukan Malaysia. Berdasarkan tinjauannya secara rambang, beliau mendakwa sokongan terhadap Filipina untuk menuntut Borneo Utara semakin meluas dalam kalangan penduduk peribumi Borneo Utara dan komuniti Cina. Artikelnya yang telah disiarkan dalam akhbar Sunday Times Magazine, turut memuatkan laporan lengkap temu bualnya dengan Sir William Goode. ${ }^{19}$

Selain dari akhbar Philippines Free Press yang menjadikan isu Borneo Utara sebagai kempen untuk mendesak Republik Filipina menuntut Borneo Utara, akhbar-akhbar tempatan lainnya seperti Manila Times, Philippine Herald, Manila Chronicle, Daily Mirror, Evening News dan Manila Daily Bulletin turut berkongsi isu yang sama terutamanya dari Disember 1961 hinggalah September 1963. Sepanjang tempoh bermula dari Januari hingga Jun 1962, Manila Daily menerbitkan kira-kira 41 isu berhubungan persoalan Borneo Utara sementara terdapat 26 isu yang diterbitkan oleh Philippine Free Press iaitu 15 atau dua pertiga daripadanya memuatkan 22 artikel mengenai persoalan Borneo Utara. Daripada jumlah 
tersebut pula, enam rencana ditulis oleh editor akhbar, sembilan artikel ditulis oleh dua orang wartawan tetap akhbar manakala selebihnya ditulis oleh individu persendirian lain. ${ }^{20}$

Antara kolumnis yang turut menulis mengenai persoalan Borneo Utara di dalam ruangan akhbar Philippines Free Press adalah editor akhbar Teodor M. Locsin, ahli kongres Jovito R. Salonga dan Alejandro M. Fernandez daripada University of the Philippines. Locsin dan Soliven selaku editor dan penerbit di akhbar Philippine Free Press dan Evening News turut memaklumkan kepada Duta Australia di Manila dalam perjumpaan yang berasingan bahawa mereka akan memastikan isu tuntutan ke atas Borneo Utara terus hidup sehinggalah Kerajaan Filipina mengambil tindakan untuk menuntut semula Borneo Utara. ${ }^{21}$ Mereka berpegang teguh dengan keyakinan bahawa tuntutan Filipina ke atas mempunyai asas yang kukuh dan kuat serta menganggap Filipina tidak akan kehilangan apa-apa seandainya tuntutan tersebut dibuat. Tambahan pula, Locsin dan Soliven merupakan antara individu yang paling lantang mengkritik peranan British di dalam Southeast Asia Treaty Organization (SEATO) ${ }^{22}$. Maka tidak hairanlah jika sekiranya kempen oleh akhbar Filipina tersebut merupakan sebahagian muslihat yang dirancang bagi memalukan dan menjatuhkan imej British.

Selain dari faktor kempen dan propaganda besar-besaran yang ditaja oleh akhbar Filipina, terdapat elemen lain yang menjadikan akhbar Filipina sebagai instrumen yang memberikan kesan signifikan terhadap pertimbangan Filipina dalam membuat keputusan mengenai persoalan Borneo Utara. Hal ini disebabkan oleh terdapatnya kolumnis yang mempunyai pengaruh besar di dalam majlis perwakilan dan pembuatan dasar kerajaan. Antaranya adalah ahli kongres Jovito R. Salonga yang juga merupakan salah seorang ahli dalam Jawatankuasa Hal Ehwal Luar Filipina dan Pengerusi Jawatankuasa Undang-Undang delegasi Filipina dalam Rundingan Anglo-Filipina di London. Penglibatan beliau di dalam kempen tajaan Philippine Free Press dan menyokong kuat tindakan untuk menuntut semula Borneo Utara sering menjadi perhatian kebanyakan ahli dewan Filipina dan sarjana Filipina. ${ }^{23}$ Malah, beliau turut menghasilkan satu terbitan khas bagi mematahkan dan menjawab laporan Senator Lorenzo Sumulong yang lebih cenderung memihak kepada British dan mempersoalkan tindakan Filipina untuk menuntut Borneo Utara. Kritikan Senator Sumulong tersebut kemudian dijawab oleh Salonga dalam sebuah terbitan bertajuk A Point by Point Reply to the Sumulong Report on the Philippine Claim to North Borneo. ${ }^{24}$

Dalam tulisannya The North Borneo Question, Salonga turut mempertahankan Borneo Utara sebagai milik sah Republik Filipina dengan merujuk beberapa dokumen penting. ${ }^{25}$ Menurut beliau, meskipun perjanjian di antara Sultan Sulu dan Baron Von Overbeck ditandatangani pada 22 Januari 1878, namun pemindahan hak ke atas Borneo Utara kepada Overbeck hanyalah sebagai individu persendirian semata-mata. Hal ini bermaksud, British North Borneo Company (BNBC) mahupun British sendiri tidak mempunyai hak pemilikan dan kedaulatan ke atas wilayah Borneo Utara malahan menganggap penyerahan Borneo Utara di bawah Piagam diraja British (Royal Charter) dan menjadi sebahagian naungan British pada 1888 seterusnya Crown Colony pada 1946 sebagai tidak sah. Walau bagaimanapun, tidak dapat dinafikan bahawa masih terdapat penulis yang mengulas isu berkaitan persoalan Borneo Utara dalam rentak yang lebih sederhana serta kurang berbaur provokasi. Terdapat juga pandangan yang tidak terlalu berat sebelah dan turut mengemukakan hujah yang memihak kepada British untuk penilaian pembaca sendiri. Misalnya, Willie Ng dalam akhbar Manila Daily Bulletin dalam ulasannya memperlihatkan sikap yang sederhana terhadap isu Borneo Utara kerana menyedari hakikat bahawa jika ia tetap diteruskan ia boleh memberi implikasi negatif terhadap kestabilan dan keharmonian rantau Asia Tenggara. ${ }^{26}$ 


\section{Tuntutan Filipina ke atas Borneo Utara}

Pada bulan Mac 1962, Napoleon G. Rama sekali lagi menggesa Republik Filipina agar bertindak segera menuntut Borneo Utara kerana pembentukan Malaysia yang direncanakan telah semakin hampir. ${ }^{27}$ Jika tiada tindakan segera diambil, Filipina hanya akan 'berputih mata' dan dipandang sebagai negara yang lemah sekali gus menjatuhkan imej Filipina kerana gagal mengemukakan tuntutannya ke atas Borneo Utara. Dalam artikel yang ditulisnya, beliau menegaskan, "the government will not permit any of its citizens to barter away the nation's sovereignty. It should not allow any foreign government to ignore or violate our sovereign rights." 28

Selain dikenali sebagai wartawan tersohor di Filipina yang pendapatnya sering menjadi perhatian awam, Rama juga merupakan seorang peguam yang mempunyai pengetahuan yang luas dalam aspek perundangan. Kelebihan ini telah digunakan sebaiknya oleh beliau untuk mendesak ahli perwakilan Filipina supaya akur dengan segala desakan dan permintaannya. Beliau juga terus menerus memberikan tekanan kepada Presiden Macapagal supaya kembali dengan pendirian lamanya pada tahun 1950 yang telah mencadangkan House Concurrent Resolution No. 42 yang menggesa kepada pemulihan wilayah Filipina. ${ }^{29}$ Pada 28 April 1950, Persidangan Kongres Filipina yang terdiri daripada tujuh ahli kongres termasuk Macapagal telah meluluskan Resolusi No. 42 yang mengisytiharkan Borneo Utara sebagai milik Filipina sekali gus menggesa Presiden Filipina mengambil langkah-langkah untuk menuntut Borneo Utara. ${ }^{30}$ Namun, resolusi tersebut gagal mendapat kelulusan di peringkat Senat. Oleh yang demikian, tiada sebarang protes dan tindakan yang efektif dilakukan oleh Filipina bagi menuntut Borneo Utara. Malahan, ketika Pejabat Kedutaan British menolak nota yang dihantar oleh pemangku Setiausaha Hubungan Luar Filipina pada tahun 1950 mengenai status perjanjian 1878 yang didakwa sebagai pajakan, tiada pula cabaran atau tindak balas terhadap penolakan tersebut yang dibuat oleh Kerajaan Filipina.

Resolusi tersebut kemudiannya dipinda pada tahun 1952, namun ia hanya mencadangkan supaya Kerajaan Filipina membeli hak dan pemilikan waris-waris Sultan Sulu ke atas Borneo Utara dan meminta bayaran pampasan pajakan yang diberikan kepada British North Borneo Company. ${ }^{31}$ Sekali lagi, masih tiada tuntutan yang dibuat oleh Kerajaan Filipina terhadap Kerajaan British. Keadaan ini adalah berikutan daripada rasa tidak yakin dan tidak berani untuk bertindak kerana kekurangan maklumat yang jelas dan secukupnya tentang hak sebenar Filipina dan waris-waris Sultan Sulu ke atas Borneo Utara. Ketidakyakinan dan keraguan tersebut berpunca kerana Sultan Sulu sendiri tidak mempunyai salinan surat perjanjian 1878, masalah mengenal pasti waris-waris Sultan Sulu yang sah, persoalan hak kedaulatan Sultan Sulu ke atas Borneo Utara, kekeliruan mengenai status surat perjanjian yakni sama ada ia bersifat pajakan atau pemberian berkekalan dan kepastian sama ada Borneo Utara adalah milik sah Sultan Sulu. ${ }^{32}$ Ketidakpastian dan kekurangan maklumat yang mencukupi itulah yang menyebabkan Filipina belum bersedia untuk mengambil tindakan untuk menuntut Borneo Utara.

Bermula dari akhir tahun 1961, barulah usaha-usaha ke arah untuk mengambil langkah menuntut semula Borneo Utara dilakukan. Selain daripada janji Macapagal sendiri dalam kempen pilihan raya Presiden Filipina yang berjanji untuk menuntut Borneo Utara, tekanan dan desakan daripada akhbar Filipina yang melancarkan kempen menuntut Borneo Utara turut menyumbang kepada pengaruh yang signifikan terhadap penentuan dan pertimbangan polisi Filipina mengenai Borneo Utara sekali gus mempercepatkan lagi tindakannya menuntut Borneo Utara. Setelah tindakan meluluskan Resolusi No. 42 dilakukan pada tahun 1950 yang memasukkan Borneo Utara sebagai sebahagian wilayah Filipina, sekali lagi pada 24 April 1962, Filipina mengambil langkah yang hampir serupa apabila Dewan Perwakilan meluluskan Resolusi No. 32 bagi menggesa Presiden Macapagal untuk mendapatkan Borneo Utara. ${ }^{33}$ Meskipun terdapat beberapa orang anggota Dewan Senat yang terlibat dalam penggubalan 
dasar luar Filipina menentang tindakan tersebut namun masih gagal mempengaruhi pendirian dan keputusan Macapagal dan ahli perwakilan untuk mengambil langkah-langkah menuntut Borneo Utara.

Pada 24 April 1962 juga, waris-waris Sultan Sulu daripada Keluarga Kiram yang diketuai oleh Sultan Muhammad Esmail Kiram menandatangani perjanjian penyerahan wilayah dan kedaulatan Borneo Utara yang dimiliki oleh Kesultanan Sulu kepada Republik Filipina. Perjanjian pengiktirafan penyerahan wilayah kepada Republik Filipina tersebut ditandatangani secara bersama oleh waris-waris Sultan Sulu yang lain termasuklah Datu Rasamuda Punyungar Kiram, Sitti Rada Kiram, Putli Tarhata Kiram dan Putli Sakinulin Kiram dengan disahkan oleh I. B. Bareja, Setiausaha Majlis Perwakilan Filipina I. B. Pareja. ${ }^{34}$ Perjanjian turut menetapkan pengguguran dan pelepasan segala instrumen, kontrak, dokumen dan kuasa yang dimiliki oleh waris-waris Sultan Sulu tersebut sebagai manifestasi pengiktirafan ke atas penyerahan tersebut. Isi kandungan perjanjian tersebut turut menyebut:

That we hereby accept and recognize the absolute, exclusive and unconditional right of the Government of the Republic of the Philippines to initiate, institute, and prosecute the claim, to the above described property through any and by all peaceful and amicable modes of international settlement, including diplomatic negotiations, conciliation, mediation, arbitration, Commission of Inquiry, report to the International Court of Justice or to the United Nations, as the circumstances may warrant, hereby adopting all that said Government may do in accordance with this document of recognition and authority. ${ }^{35}$

Berdasarkan petikan tersebut, dalam perenggan ketiga dokumen tersebut, menyatakan bahawa waris-waris Sultan Sulu menyerahkan seluruh hak, kekuasaan dan kedaulatan yang dimiliki kepada Republik Filipina sekali gus mengambil alih usaha ke arah menuntut semula Borneo Utara sama ada melalui jalan diplomatik mahupun menerusi jalan perundangan iaitu membawa kes tuntutan tersebut kepada International Court of Justice (ICJ). Keadaan ini secara tidak langsung menjadi petunjuk bahawa secara rasminya, kedaulatan Kesultanan Sulu ke atas Borneo Utara yang dipertahankan sebelumnya juga turut terhapus. Perjanjian yang ditandatangani di Manila tersebut juga memberikan satu kelebihan buat Filipina untuk mengukuhkan kedudukan dan kuasanya sekali gus menjadi kekuatan buatnya untuk mengemukakan tuntutan rasminya ke atas Borneo Utara kepada pihak British.

Kemuncak kepada tekanan yang bertali arus ekoran kempen tuntutan ke atas Borneo Utara yang dimainkan oleh akhbar Filipina akhirnya Filipina dengan majoriti ahli Dewan Perwakilan sebulat suara bersetuju untuk mengambil tindakan menuntut semula Borneo Utara daripada Kerajaan British. Keputusan ini juga diambil bagi menjaga maruah Filipina daripada dianggap sebagai negara yang lemah kerana tidak mampu mempertahankan wilayah kekuasaan dan kedaulatannya. Akhirnya, pada 22 Jun 1962, Filipina telah menghantar aidememoire buat pertama kalinya kepada British bagi mempersoalkan pemilikan dan kedaulatan sebenar ke atas Borneo Utara. British dalam aide-memoire nya kepada Filipina pula menegaskan bahawa tuntutan Filipina tersebut sebagai tidak berasas dan turut menasihati Filipina supaya tidak mengambil tindakan terburu-buru yang mungkin menjejaskan hubungan luar Filipina dan British.

Sebagai respons terhadap tuntutan rasmi Filipina tersebut, akhbar Philippines Free Press meneruskan lagi penerbitan isu berkenaan Borneo Utara termasuklah dua rencana editor dan lima artikel mengenainya. Rama juga turut menyatakan penghargaannya kepada Presiden 
Macapagal dalam artikelnya kerana telah mengambil tindakan formal bagi menuntut semula Borneo Utara. Beliau menyebutkan bahawa:

...Ignorance, malice and fear were the only arguments
employed against the Philippine claim to North Borneo. The
president's formal filing of the claim should resolve the internal
controversy once and for all. It has become the country's claim,
the country's cause. It is time for everyone, including the
skeptics and critics to join hands in supporting the Philippines's
case. ${ }^{36}$

Semenjak dari hari aide-memoire itu dihantar dan pengumuman yang dibuat oleh Presiden Macapagal mengenai tuntutan tersebut, pertikaian demi pertikaian terus berlaku di antara Filipina, British dan Tanah Melayu. Situasi ini juga telah menyebabkan hubungan dua hala antara Filipina dan Tanah Melayu buat pertama kalinya tercalar teruk semenjak terjalinnya hubungan bilateral di antara dua negara tersebut pada tahun 1959. Pertikaian ini berterusan sehinggalah selepas pembentukan Malaysia. Pengumuman tuntutan rasmi ke atas Borneo Utara merupakan suatu perkara yang amat mengejutkan dan di luar jangkaan jika dilihat dari konteks polisi hubungan luar Filipina namun ia sama sekali tidak mengejutkan jika ditinjau dari kerangka perkembangan dalam negara Filipina. Hal ini jelas berdasarkan pengaruh dan desakan daripada waris-waris Sultan Sulu, kempen dan propaganda akhbar tempatan Filipina, peranan yang dimainkan oleh politikus Filipina serta hasrat Macapagal sendiri yang sememangnya sudah lama memendam hasrat untuk menuntut Borneo Utara. Namun, jika ditinjau berdasarkan kepada polisi luar Filipina, sememangnya ia menjadi satu keputusan yang jauh bertentangan prinsip dasar luarnya yakni menjaga dan mengeratkan hubungan luarnya dengan menjalinkan kerjasama yang baik dengan negara-negara serantau. Jelasnya, berdasarkan perkembangan ini, faktor dalaman seperti tekanan yang diberikan oleh akhbar Filipina juga menjadi asas dan panduan kepada penentuan dasar luar Filipina.

\section{Kesimpulan}

Pengaruh akhbar tempatan Filipina terhadap persoalan Borneo Utara bukan sahaja berjaya membuka mata masyarakat Filipina mengenai hak dan sejarah silam Kerajaan Sulu tetapi juga menjadi instrumen penting ke arah pembentukan polisi Republik Filipina terhadap Borneo Utara. Dalam konteks yang lebih luas, peranan yang dimainkan oleh akhbar-akhbar Filipina benar-benar menggugat keharmonian dan kestabilan hubungan bilateral Filipina-Malaysia. Keadaan yang sama turut berlaku di era pemerintahan Presiden Marcos apabila beliau sendiri turut merasa tertekan dengan tindakan akhbar Filipina sangat sukar untuk dikawal dan meminta supaya Tun Razak tidak terlalu terkesan dengan berita-berita yang dikeluarkan oleh akhbar Filipina. Walau bagaimanapun, keadaan ini tidaklah bererti presiden Filipina langsung tidak mempunyai pengaruh ke atas akhbar-akhbar utamanya. Hal ini kerana, Presiden Macapagal sendiri umpamanya dikatakan sudah sedia maklum dan meluluskan artikel-artikel yang bakal diterbitkan mengenai isu Borneo Utara kerana beliau sendiri mahu meninjau reaksi kerajaan Tanah Melayu dan British terhadap isu tersebut.

Persoalan yang sering dibangkitkan oleh kebanyakan akhbar Filipina termasuklah mengenai hak pemilikan sebenar ke atas Borneo Utara. Pasca pembentukan Malaysia pula memperlihatkan isu-isu yang sering dibahaskan lebih tertumpu kepada isu mempertikaikan penggabungan Borneo Utara bersama Malaysia dan serangan terhadap kepimpinan Tunku Abdul Rahman kerana dianggap tidak menghormati hubungan bilateral Filipina-Tanah Melayu serta mengkhianati perjanjian dalam rundingan di Manila. Isu tuntutan Filipina ke atas Borneo Utara bolehlah diumpamakan seperti sarang tebuan yang sekiranya dijolok, 
pastinya ia akan menyengat dengan sengatan paling berbisa. Isu ini kadangkala dipandang sepi namun akan kembali mewarnai perkembangan geo-politik semasa jika ia sengaja dihidupkan oleh pihak-pihak yang berkepentingan.

\section{Nota}

${ }^{1}$ Duta Australia di Manila berpandangan bahawa situasi yang berlaku di negara jiran Filipina yakni Indonesia yang cuba mendapatkan semula Papua Barat telah menjadi pendorong kepada wartawan Filipina mengadakan kempen menuntut Borneo Utara. DO 169/127, Sultan of Sulu's Heirs Claim to North Borneo. Lihat Surat Duta Australia di Manila kepada Department of External Affairs, North Borneo, 6 Februari 1962. Khuatir dengan kempen yang dilancarkan oleh akhbar-akhbar tempatan Filipina tersebut yang mempersoalkan kedaulatan Borneo Utara sekali gus mendesak kerajaan Filipina menuntut Borneo Utara, British telah menggunakan saluran diplomatiknya untuk mendapatkan kerjasama Amerika Syarikat bagi memberikan tekanan kepada Filipina supaya tidak bertindak lebih jauh. Dalam masa yang sama, British juga turut menasihati Kuala Lumpur agar berusaha untuk memujuk Filipina menerusi saluran Association of Southeast Asia (ASA). Rujuk surat R. C. Ormerod kepada Mr. Hampshire, 7 Februari 1962. Ketika kajian terperinci mengenai Borneo Utara sedang dilaksanakan oleh Republik Filipina, Emmanuel Pelaez selaku Setiausaha Hubungan Luar Filipina memberikan jaminan bahawa Filipina tidak akan membenarkan isu pertikaian ke atas Borneo Utara menjadi penghalang kepada kesatuan dalam ASA. Lihat The Philippine Press International News Service, 2 April 1962.

${ }^{2}$ Beliau juga telah menulis surat kepada pihak British bagi menuntut hak waris-waris Sultan Sulu ke atas Borneo Utara, selain turut menuntut bayaran ganti rugi. Ibid.

3 Akhbar Philippines Free Press ditubuhkan pada tahun Ogos 1908 dan sehingga tahun 1964 ia berjaya mencapai lebih 60,000 hingga 64,000 edaran. Lihat Jean Grossholtz, Politics in the Philippines, Boston: Little, Brown and Company, 1964, hlm. 205. Akhbar mingguan ini adalah akhbar arus perdana yang memuatkan pelbagai isu mengenai pentadbiran Filipina dan perkembangan politik semasa Filipina.

${ }^{4}$ Napoleon G. Rama, 'North Borneo is Ours', Philippines Free Press, 20 Januari 1962. Sebelumnya iaitu pada 30 Disember 1961, Napoleon telah pun menghasilkan artikel yang turut diterbitkan dalam akhbar yang sama yang bertajuk North Borneo Belongs To Us.

${ }^{5}$ Cadangan untuk mempersoalkan kedaulatan Borneo Utara pada awalnya sudah bermula sejak Filipina mencapai kemerdekaan lagi. pada tahun 1946, Filipina ada mempersoalkan penyerahan kedaulatan Borneo Utara oleh pihak syarikat kepada Kerajaan British, namun ia tidak disusuli dengan sebarang desakan mahupun tuntutan yang efektif untuk menuntut Borneo Utara. Selepas itu, tidak lagi kedengaran isu kedaulatan Borneo Utara dibangkitkan oleh Filipina sehinggalah pada tahun 1950 dan 1952, resolusi mengenai Sabah diluluskan yang menggesa Presiden Filipina untuk mendapatkan Sabah. Walau bagaimanapun, sekali lagi ia langkah-langkah yang signifikan gagal dilaksanakan bagi menuntut Sabah. The Facts About Sabah, Manila: National Media Production Center, 1968, hlm. 2. Lihat juga Fernandez, E. S., 'Philippine-Malaysia Dispute over Sabah: A Bibliographic Survey’, Asia-Pacific Social Science Review, Vol. 7, No. 1 (Disember 2007), hlm. 54.

${ }^{6}$ Antara peguam-peguam yang dilantik termasuklah Calixto de Leon yang menuntut sambungan bayaran pajakan pada tahun 1936, Teopista Guingona pada tahun 1946, Agripino Escariel pada tahun 1947, Antonio Quirino pada tahun 1948, Vicente Gariel pada tahun 1957, Nicasio Osmena dari tahun 1957 hingga 1961 dan Juan Orendain pada tahun 1962. Lihat Josue Silao Dizon, The Foreign Policy of the Philippines with Special Emphasis on the Macapagal Administration, 1961-1965, Amerika Syarikat: University Microfilms, Inc., 1978, hlm. 213.

${ }^{7}$ Surat Perjanjian antara Sultan Sulu, Sultan Jamalul 'Azam dengan Baron Von Overbeck, 22 Januari 1878, Public Record Office, London. Sultan Jamalul ‘Azam juga telah melantik Overbeck sebagai Dato’ Bendahara dan Raja Sandakan. Lihat juga Grant by the Sultan of Sulu of a Permanent Lease Covering His Lands and Territories on the Island of Borneo, 22 Januari 1878, Translation by Professor Conklin of the Deed of 1878, Great Britain and Netherlands: Grant from the Sultan of Sulu to Baron de Overbeck and Alfred Dent, Esquire, of certain territories and lands on the mainland of the Island of Borneo, 22 January 1878, hlm. 1082-1083. Untuk keterangan lanjut mengenai pembatalan perjanjian 1878, sila rujuk FCO 15/303, Philippines: Political Affairs (Bilateral), Malaysia. Rujuk Instrument of Cession of the Territory of North Borneo by His Highness Sultan Mohammad Esmail Kiram, Sultan of Sulu, Acting with the Advice and Authority of the Ruma Bechara, to the Republic of the Philippines, 12 September 1962. Notis pembatalan Perjanjian Serahan 1878 tersebut telah disampaikan oleh peguamnya, Vicente D. Gabriel kepada Duta British di Manila. Esmail Kiram juga bersetuju untuk mengadakan rundingan dengan pihak British jika syarat-syarat tertentu dapat dipenuhi. Lihat CO 1030/536, F. S. Tomlinson kepada W. I. J. Wallace, 13 Januari 1958. 
${ }^{8}$ FCO 15/303, Philippines: Political Affairs (Bilateral), Malaysia. Rujuk Instrument of Cession of the Territory of North Borneo by His Highness Sultan Mohammad Esmail Kiram, Sultan of Sulu, Acting with the Advice and Authority of the Ruma Bechara, to the Republic of the Philippines, 12 September 1962.

${ }^{9}$ Lihat Manila Times, 29 Mac 1962; The Manila Chronicle, 3 April 1962; Manila Times, 4 April 1962; Manila Bulletin, 4 April 1962. Artikel yang dimuatkan di dalam akhbar Manila Bulletin turut menggesa Kerajaan Filipina supaya segera menuntut Borneo Utara tanpa berlengah-lengah lagi serta mendakwa pertentangan tradisi antara masyarakat Kristian-Muslim di Filipina menjadi punca kepada tertangguhnya tuntutan dibuat ke atas Borneo Utara. Lihat Manila Bulletin, 29 Mac 1962.

${ }^{10}$ Napoleon G. Rama, 'North Borneo Belongs To Us', Philippines Free Press, 30 Disember 1961, hlm. 4-5, 5864.

${ }^{11}$ Antara dokumen yang dirujuk Rama adalah Official letter from the Governor General of the Philippines Islands bearing, 20 Ogos 1878, Report of the Commander-General of the Navy, 4 April 1878 dan Transcripts of six documents referring to the correspondence of the Governor of Jolo.

${ }^{12}$ Napoleon G. Rama, North Borneo is Ours, hlm. 5 dan 66.

${ }^{13}$ Beliau terus menerus memberi desakan terhadap Kerajaan Filipina agar mengambil tindakan segera menuntut Borneo Utara. Antara artikel lain yang ditulis bagi memberikan tekanan kepada Filipina adalah "The North Borneo Case”, Philippines Free Press, 10 Mac 1962, "Congressman Diosdado Macapagal on North Borneo", Philippines Free Press, 21 April 1962, "House Unanimously Adopts North Borneo Resolution”, Philippines Free Press, 5 Mei 1962.

${ }^{14}$ Nik Anuar Nik Mahmud, Tuntutan Filipina ke atas Borneo Utara. Bangi: Penerbit Universiti Kebangsaan Malaysia, 2009, hlm. 65. Selain itu, Maximo V. Soliven salah seorang kolumnis dalam akhbar The Philippine Herald turut menyatakan sokongannya kepada Putri Tarhata Kiram dan mendesak Republik Filipina untuk membawa kes tuntutan ke atas Borneo Utara secara langsung kepada Tunku Abdul Rahman. Lihat M. V. Soliven, “A Word Edgewise”, The Philippines Herald, 3 Februari 1962.

${ }^{15}$ Ernesto del Rosario, "Off the Beat”, The Manila Chronicle, 14 dan 19 April 1962.

${ }^{16}$ Ernesto O. Granada, "Behind Page One”, The Manila Chronicle, 6 February 1962. Lihat juga artikelnya lain 10 Februari, 25 Mei, 6 dan 28 Jun 1962 di dalam Manila Chronicle yang turut membincangkan perihal tuntutan ke atas Borneo Utara.

${ }^{17}$ Manila Chronicle, 27 Mac 1962.

${ }^{18}$ Philippine Free Press, 31 Mac 1962.

${ }^{19}$ Sunday Times Magazine, 1 April 1962.

${ }^{20}$ Nestor Martinez Nisperos, Philippine Foreign Policy on the North Borneo Question, Ann Arbor: Xerox University Microfilms, 1977, hlm. 138 -139. Banyak lagi akhbar lagi yang turut membuat liputan mengenai isu Borneo Utara, namun hanya beberapa akhbar utama di Manila sahaja yang diberikan perhatian dalam penulisan ini.

${ }^{21}$ Namun, Lee berpandangan Emmanuel Pelaez, Timbalan Presiden Filipina tidak mempunyai apa-apa kaitan dan pengaruh terhadap kempen oleh media Filipina tersebut. Lihat Surat Duta Australia di Manila kepada Department of External Affairs, North Borneo, 6 Februari 1962.

${ }^{22}$ SEATO adalah satu kerjasama pertahanan yang melibatkan negara Amerika Syarikat, Perancis, Britain, New Zealand, Australia, Filipina, Thailand dan Pakistan bagi menyekat pengaruh komunis dan mengekalkan keselamatan rantau Asia Tenggara.

${ }^{23}$ Jovito R. Salonga, “The North Borneo Question”, Philippine Free Press, 5 Mei 1962, hlm. 4, 33-35, 65.

${ }^{24}$ Senator Sumulong adalah ahli kongres yang lantang mempersoalkan tindakan Filipina yang menurutnya tidak munaBorneo Utara kerana menuntut seluruh Borneo Utara sedangkan hak dan kedaulatan sebenar Kesultanan Sulu hanya di kawasan Pantai Timur Borneo Utara. Beliau telah membidas kelemahan Presiden Macapagal dalam ucapannya pada 25 Mac 1963 di Dewan Senat dan kemudiannya diterbitkan sebagai laporan khas bertajuk A Report to the Senate and to Our People on Malaysia and on the Greater Malayan Confederation Proposed by President Macapagal in Connection with the Philippine Claim of Sovereignty to a Portion of North Borneo. Jovito R. S. A Point By Point Reply To The Sumulong Report On The Philippine Claim To North Borneo. Manila: Republic Of The Philippines House Of The Representatives Manila, 1963.

${ }^{25}$ Jovito R. Salonga, 'The North Borneo Question', Philippine Free Press, 5 Mei 1962, hlm. 4, 33-35 dan 65.

${ }^{26}$ Willie Ng, 'Column 8' dalam The Manila Daily Bulletin, 25 Januari 1962.

${ }^{27}$ Napoleon G. Rama, 'The North Borneo Case-Now Or Never', Philippines Free Press, 10 Mac 1962, hlm. 7, 74-75.

${ }^{28}$ Ibid.

${ }^{29}$ Napoleon G. Rama, 'Congressman Diosdado Macapagal on North Borneo’, Philippines Free Press, 21 April 1962, hlm. 6, 90-91.

${ }^{30}$ The Facts About Borneo Utara, Manila: National Media Production Center, 1968, hlm. 2. 
31 Josue Silao Dizon, The Foreign Policy of the Philippines with Special Emphasis on the Macapagal Administration, 1961-1965, Amerika Syarikat: The American University, 1978, hlm. 214.

${ }^{32}$ Ibid., hlm. 214-215.

33 The Facts About Borneo Utara, Manila: National Media Production Center, 1968, hlm. 2. Lihat juga Josue Silao Dizon, The Foreign Policy of the Philippines with Special Emphasis on the Macapagal Administration, 1961-1965, hlm. 216.

${ }^{34}$ Antara yang turut tercatat di dalam surat perjanjian tersebut adalah maklumat mengenai sijil pendaftaran kewarganegaraan waris-waris Sultan Sulu tersebut sebagai membuktikan status kerakyatan mereka di Filipina. Ibid.

${ }^{35}$ Ibid.

${ }^{36}$ Napoleon G. Rama, ‘The North Borneo Case’, Philippine Free Press, 30 Jun 1962, hlm. 3 dan 83-84. 